\title{
Pengaruh Budaya Modern Terhadap Kebudayaan Asli Kasepuhan Sinar Resmi
}

\author{
Muhamad Johani. ${ }^{1}{ }^{*}$ Rinawati $^{1}$ dan Japar ${ }^{1}$ \\ ${ }^{I}$ Program, Magister PPKn STKIP Arrahmaniyah Depok, Indonesia
}

\begin{abstract}
Abstrak-Tujuan dari penelitian ini yaitu untuk mengetahui pengaruh budaya modern terhadap kebudayaan asli kasepuhan Sinar Resmi. Penelitian ini berlatar belakang kekhawatiran peneliti terhadap kelestarian nilai-nilai tradisi budaya yang dimiliki masyarakat adat di Kasepuhan Sinar Resmi dalam era modernisasi. Berlatar belakang dari permasalahan tersebut, diperlukan upaya untuk mempertahankan nilai tradisi budaya yang ada agar tetap terpelihara di tengah-tengah era modernisasi. Pada pelaksanaannya, peneliti melakukan penelitian dengan menggunakan metode historis yang terdiri dari pengumpulan sumber, kritik sumber, dan historiografi. Untuk mempermudah analisis, peneliti menggunakan pendekatan interdisipliner melalui kajian ilmu sosiologi dan antropologi. Berdasarkan hasil penelitian, diketahui bahwa masyarakat adat Kasepuhan Sinar Resmi merupakan masyarakat yang masih memelihara adat tradisi dalam hal pertanian padi atau tradisi dalam menghormati Dewi Sri. Selain itu, masyarakat adat memiliki aturan-aturan adat lainnya yang harus dilaksanakan, hanya saja aspek modernisasi menjadi salah satu faktor yang menyebabkan terkikisnya nilainilai sosial dan budaya yang berlaku. Menanggapi hal tersebut, pemerintah maupun masyarakat adat melakukan beberapa upaya untuk mempertahankan nilai adat tradisi tersebut. Penelitian ini diharapkan dapat menjadi referensi bagi penelitian berikutnya, sehingga dapat menghadirkan fakta-fakta baru yang belum terungkap dari penelitian ini.
\end{abstract}

\author{
Kata kunci: \\ Budaya Modern, \\ Kebudayaan Asli, \\ Kasepuhan Sinar Resmi
}

\section{Histori:}

Dikirim: 20 Agustus 2021

Direvisi: 30 September 2021

Diterima: 30 Maret 2021

Online: 30 September 2021

(c) (i) (2) Author(s) agree that this article remains permanently open access under the terms of the Creative Commons Attribution-ShareAlike 4.0 International License

\section{Identitas Artikel:}

Johani, M., Rinawati., R., \& Japar, J. (2021). Pengaruh Budaya Modern Terhadap Kebudayaan Asli Kasepuhan Sinar Resmi. Jurnal Citizenship Virtues, 1(2), 105-112

\section{PENDAHULUAN}

Negara Indonesia adalah salah satu negara multikultur terbesar di dunia, hal ini dapat terlihat dari kondisi sosiokultural maupun geografis Indonesia yang begitu kompleks, beragam, dan luas. Indonesia terdiri dari sejumlah besar kelompok etnis, budaya, agama yang heterogen atau beraneka ragam. Hasil dari kerjasama BPS dan ISEAS (Institute of South Asian Studies) merumuskan bahwa terdapat sekitar 633 suku yang diperoleh dari pengelompokan suku dan subsuku yang ada di Indonesia (Kusumohamidjojo, 2000). Ribuan pulau yang ada di

\footnotetext{
${ }^{1}$ *Corresponding author.

E-mail: ri3napooter@gmail.com
} 
Negara Kesatuan Republik Indonesia merupakan salah satu ciri bahwa negara ini memiliki keragaman suku dan latar belakang kebudayaan yang berbeda-beda. Kondisi Indonesia yang terdiri dari beraneka ragam tradisi, adat, suku, dan budaya menyebabkan adanya keunikan atau karakteristik dari setiap suku yang ada.

Ciri khas dari suatu kebudayaan dapat diartikan sebagai suatu unsur kecil yang tidak dimiliki oleh kebudayaan lain. Budaya yang memiliki ciri khas tersendiri salah satunya adalah kebudayaan suku Sunda. Budaya Sunda memiliki ciri khas dengan kepribadian dan identitas khususnya, dan tentunya hal ini membedakan kebudayaan yang dimiliki suku Sunda dengan kebudayaan lainnya (Koentjaraningrat, 2009). Adapun istilah Sunda berdasarkan geografis menunjukan pengertian wilayah di bagian barat Pulau Jawa dengan segala aktivitas kehidupan manusia di dalamnya dan hanya mengandung arti yang berkaitan erat dengan pembagian wilayah administrasi. Sedangkan dalam pengertian kebudayaan, Sunda diartikan sebagai kebudayaan yang hidup, tumbuh, dan berkembang di kalangan orang Sunda yang pada umumnya berdomisili di tanah Sunda (Ekadjati, 2014).

Hal menarik lainnya yang dapat dilihat dari kearifan lokal budaya Sunda yang masih ada hingga saat ini adalah mengenai ekologi kampung Sunda. Kelestarian ekologi kampung Sunda yang masih ada hingga saat ini tercermin dengan adanya kampung-kampung adat yang tersebar di wilayah Jawa Barat. Kampung-kampung di daerah perdesaan tanah Sunda selalu terbagi dalam tiga hunian besar (dusun) yang terdiri dari kampung tertua atau kabuyutan, kampung modern, dan kampung yang mengurusi agama Islam (Sumardjo, 2011). Kampung kabuyutan selalu bersifat masih memelihara adat istiadat Sunda dan biasa dikenal dengan sebutan kampung adat. Kampung adat merupakan sebuah kesatuan masyarakat hukum adat yang secara historis mempunyai batas wilayah dan identitas budaya yang terbentuk atas dasar teritorial yang berwenang mengatur dan mengurus kepentingan masyarakat (Afifah, 2016). Kewenangan tersebut sangat menentukan kebijakan yang akan ditetapkan. Kebijkan tidak bisa bertentangan dengan norma-norma dan nilai-nilai yang berlaku pada masyarakat. Apabila kebijkan mengandung nilai-nilai yang tidak sesuai dengan norma yang ada pada masyarakat, maka kebijakan itu bisa menjadi kendala pada saat diimplementasikan. Sebaliknya, suatu kebijakan harus dapat mengakomodir nilai-nilai serta praktik-praktik yang ada dan berkembang dalam masyarakat.(Pudjiastuti, dkk; 2021)

Kampung dalam pengertian kampung adat, mengacu kepada kelompok tradisional dengan dasar ikatan adat istiadat. Kampung adat biasanya memiliki pola pikir dan pola kehidupan yang berbeda dengan kampung biasa lainnya. Selain itu, menurut Surpha (Pitana;1994), menyatakan bahwa kampung adat adalah suatu komunitas tradisional dengan fokus fungsi dalam bidang adat dan tradisi, dan merupakan satu kesatuan wilayah dimana para anggotanya secara bersama-sama melaksanakan kegiatan sosial dan tradisi yang ditata oleh suatu sistem budaya. Dari berbagai pendapat diatas, dapat disimpulkan bahwa kampung adat merupakan warisan organisasi pemerintahan lokal yang dipelihara secara turun temurun dan tetap diakui serta diperjuangkan oleh pemimpin dan masyarakat desa adat agar dapat berfungsi mengembangkan kesejahteraan dan identitas sosial budaya local.

Adapun kampung kabuyutan Sunda biasanya dihuni oleh sekelompok masyarakat yang masih memelihara adat istiadat lama atau dapat disebut dengan 
masyarakat adat. Kampung-kampung adat yang berada di wilayah Jawa Barat misalnya seperti Kampung Suku Baduy di Banten, Kampung Banceuy di Kabupaten Subang, Kampung Naga di Tasikmalaya, Kampung Dukuh di Garut, Kampung Kuta di Ciamis, Kampung Mahmud di Kabupaten Bandung, Kampung Adat Sinar Resmi, Kampung Adat Cipta Gelar, juga Kampung Adat Cipta Mulya yang ketiganya berada di wilayah Kabupaten Sukabumi. Adapun kampung adat yang akan dibahas dalam skripsi ini adalah kampung adat yang bernama Kasepuhan Sinar Resmi dan berlokasi di Desa Sirna Resmi, Kabupaten Sukabumi.

\section{METODE PENELITIAN}

Metode yang dilakukan oleh peneliti dalam mengkaji permasalahan yang berkaitan dengan judul adalah metode historis dengan menggunakan studi literatur serta wawancara sebagai tekniknya. Studi literatur dilakukan dengan membaca dan mengkaji buku-buku, artikel, jurnal, dan beberapa dokumen karya ilmiah lainnya yang berkaitan dengan penelitian ini. Kemudian teknik wawancara dilakukan dengan melakukan wawancara dengan nara sumber yang berkaitan dengan penelitian yang dikaji.(Pudjiastuti;2019)

Selain itu dalam melakukan penelitian ini, peneliti menggunakan pendekatan interdisipliner yang diharapkan dapat membantu proses penelitian yang dilakukan. Penelitian interdisipliner merupakan pendekatan dalam satu rumpun ilmu dan menjadikan salah satu disiplin ilmu sebagai kajian utama (Hasan,1996). Adapun dalam penelitian ini, peneliti mengkaji permasalahan topik dalam ilmu sejarah serta menggunakan ilmu bantu sosiologi dan antropologi dalam penulisannya. Ilmu-ilmu bantu yang digunakan berfungsi sebagai pelengkap atau penunjang dalam mengkaji konsep-konsep ilmu sosial dalam analisis penelitian.

Selain sumber tertulis, peneliti pun melakukan pencarian sumber lisan dengan melakukan wawancara kepada narasumber yang berkaitan dengan pembahasan atau permasalahan yang dikaji oleh peneliti, seperti pihak masyarakat adat Kasepuhan Sinar Resmi, pihak pemerintah daerah Kabupaten Sukabumi khususnya Dinas Budaya Pemuda dan Olahraga. Dalam tahap heuristik, peneliti menggunakan teknik-teknik guna mempermudah pelaksanaan heuristik di lapangan yaitu studi literatur, studi dokumentasi serta wawancara. Teknik yang digunakan ini merupakan upaya yang dilakukan peneliti guna mengumpulkan berbagai informasi yang berkaitan dengan permasalahan yang dikaji.

\section{HASIL DAN PEMBAHASAN}

Kasepuhan Sinar Resmi merupakan salah satu kasepuhan yang ada di Desa Sirna Resmi, Kecamatan Cisolok, Kabupaten Sukabumi. Sebelum menempati wilayah Desa Sirna Resmi, awalnya kasepuhan ini berada di Desa Cicemet dan pada tahun 1959 kemudian pindah menempati Desa Cikaret atau yang saat ini disebut Desa

Sirna Resmi. Adapun perpindahan tersebut dikarenakan pola hidup masyarakatnya yang saat itu masih berpindah-pindah dan faktor-faktor lainnya. Kasepuhan Sinar Resmi merupakan bagian dari Komunitas Kesatuan Adat Banten Kidul. Komunitas Kesatuan Adat Banten Kidul merupakan identitas sebuah komunitas tradisional yang terdiri dari beberapa kasepuhan adat, cakupan wilayahnya terdapat di Kabupaten Sukabumi, Kabupaten Bogor, dan Kabupaten Lebak (Provinsi Banten) (Hendarti, 2008). 
Kampung adat atau kasepuhan yang berada di wilayah Kabupaten Sukabumi terdiri dari tiga kasepuhan yang masih berasal dari leluhur yang sama yaitu, Kasepuhan Sinar Resmi, Kasepuhan Cipta Gelar, dan Kasepuhan Cipta Mulya. Sebuah kasepuhan memiliki makna tersirat sebagai suatu komunitas yang berupaya dalam pelestarian dari nilai-nilai tradisi yang diwariskan oleh nenek moyang, dan disebut sebagai tatali paranti karuhun (Mawaddahni, 2017). Adapun masyarakat adat di Kasepuhan Sinar Resmi merupakan salah satu kelompok masyarakat adat Komunitas Adat Banten Kidul yang aktivitas kehidupannya masih menjalankan cara-cara tradisi Sunda lama hingga saat ini. Tradisi-tradisi yang diwariskan leluhurnya misalnya seperti dalam hal pertanian, aturan dalam membuat rumah, ritual pernikahan, serta upcara adat lainnya. Tradisi pertanian tersebut berupa aturan penanaman padi setahun sekali, penggunaan benih lokal, serta ritual-ritual lainnya yang dilaksanakan dalam setiap tahap penanaman padi baik di sawah maupun di huma (ladang) dengan cara yang masih tradisional. Selain itu terdapat aturan atap rumah yang tidak boleh terbuat dari genting dan harus menggunakan atap rumbia dan injuk, tidak boleh memasak memakai kompor harus memakai tungku dengan menggunakan kayu bakar (Mutaqin \& Iryana, 2018). Tradisi-tradisi tersebut tentu akan membentuk pola sosial budaya yang unik dan membedakannya dengan masyarakat lainnya. Tradisi adat dalam aspek pertanian yang masih terpelihara juga disebabkan latar belakang geografis Kasepuhan Sinar Resmi yang terletak di perdesaan kaki gunung, hal tersebut membuat masyarakatnya kemudian mengandalkan sektor agraris dan bermata pencaharian sebagai petani dalam kehidupan sehari-harinya. Masyarakat adat yang berada di Kasepuhan Sinar Resmi memang dikenal sebagai masyarakat yang memelihara adat-adat dalam bentuk pertanian dan memuliakan Dewi Sri atau Dewi Padi dalam kehidupannya. Bentuk-bentuk tradisi dalam memuliakan padi tercermin dalam berbagai aturan adat dalam penanaman padi itu sendiri dan dalam tradisi pertanian lainnya.

Meskipun masih menerapkan aturan-aturan adat dalam kehidupan sehariharinya, namun jika diteliti lebih lanjut terdapat beberapa perubahan baik dalam aspek sosial maupun budaya yang terjadi pada masyarakat di Kasepuhan Sinar Resmi yang terjadi saat ini. Perubahan tersebut tidak terlepas dari proses perkembangan secara bertahap dengan semakin majunya perkembangan hidup manusia dan penyesuaian dengan lingkungannya. Perubahan sosial dan budaya yang terjadi pada masyarakat Kasepuhan Sinar Resmi dapat dilihat dengan masuknya unsur-unsur modern dalam kehidupan masyarakat adat. Modernisasi berarti "suatu transformasi total kehidupan bersama yang tradisional atau pra modern dalam arti teknologi dan membentuk pola-pola ekonomis dan politis" (Soekanto, 2006). Sedangkan menurut Cyril Edwin Black (Setiadi, 2006), mengatakan bahwa "modernisasi adalah serangkaian perubahan cara hidup manusia yang kompleks dan saling berhubungan, dan pengalaman yang bersifat universal". Berdasarkan pengertian tersebut dapat disimpulkan bahwa modernisasi dianggap sebagai pembaruan dalam kehidupan dan bertujuan sebagai usaha penyesuaian dengan perkembangan dunia.

Perubahan-perubahan yang terjadi dalam masyarakat adat di Kasepuhan Sinar Resmi dapat dilihat dari mulai adanya rumah-rumah yang memakai atap dari genting dan dinding tembok, penggunaan barang-barang elektronik dan teknologi dalam kehidupan sehari-hari, adanya para penduduk yang mulai keluar 
kampung adat baik untuk menetap atau bekerja, pola interaksi yang semakin luas dengan masyarakat luar, dan lainnya. Selain itu perubahan juga terjadi dalam aspek keagamaan dan kesenian yang semakin maju. Modernisasi yang terjadi pada masyarakat Kasepuhan Sinar Resmi terjadi akibat adanya berbagai peristiwa yang melatarbelakanginya. Perubahan-perubahan pada aspek sosial dan budaya tersebut terjadi akibat adanya reaksi masyarakat terhadap perkembangan zaman yang semakin canggih dan modern. Hal ini membuat masyarakat untuk terus melakukan inovasi serta penyesuaian terhadap lingkungannya. Terkait dengan perubahan-perubahan yang terjadi serta upaya-upaya pelestarian tradisi yang dilakukan oleh masyarakat adat Kasepuhan Sinar Resmi dalam menghadapi arus modernisasi tersebut, sebagai berikut: (1) Orientasi nilai budaya yang berlaku di kasepuhan ini adalah Hidup itu baik. Menjaga kelestarian alam, tidak hanya didorong oleh kesadaran bahwa bencana akan datang jika alam tak dijaga. Tetapi juga sebagai bentuk ketaatan seorang muslim. Karena Allah memerintah kita agar berbuat baik, maka berbuat baik terhadap alam adalah juga bentuk ketaatan.(Pudjiastuti,dkk;2021) Hal ini terbukti dengan upaya mereka untuk terus mempertahankan budaya dalam bercocok tanam yang hanya dilakukan setahun sekali sehingga kehidupan mereka tetap baik dan tetap bisa hidup di kermudian hari. Nilai budaya mengenai hakekat dari karya manusia. Orientasi nilai budaya yang berlaku pada kasepuhan Sinar Resmi adalah Karya itu untuk nafkah hidup. Hal ini terbukti bahwa mereka tidak pernah berupaya untuk merubah pola tanam padi menjadi lebih dari satu kali dalam setahun. Mereka tidak pernah ngoyo dan rakus untuk memperoleh penghasilan karena mereka berkarya untuk nafkah hidup dan tidak hidup untuk terus berkarya. Mereka juga tidak menggunakan pupuk untuk sawahnya tapi setelah menanam padi. Sawah itu dibiarkan tumbuh bergantung pada alam. Tapi mereka menanam padi di huma/ Nilai budaya mengenai hakekat dan kedudukan manusia dalam ruang waktu. Nilai budaya mengenai hakekat dan kedudukan manusia dalam ruang waktu di kasepuhan Sinar Resmi adalah warga sangat berorientasi ke masa yang akan datang. Hal ini bisa dilihat dari adanya tradisi menyimpan padi di lumbung padi yang disebut "leuit" dan sistem pertanian yang dilakukan. Leuit yaitu lumbung padi merupakan simbol ketahanan pangan bagi masyarakat tersebut karena leuit merupakan tempat untuk menyimpan gabah hasil panen. Nilai budaya yang diturunkan dari generasi ke generasi adalah "ngeureut neundeun keur jaganing isuk" (menyisihkan untuk hari depan) mempunyai makna flosof yang sangat berharga bagi warga kampung adat secara keseluruhan. Manusia diingatkan untuk tidak rakus dengan menghabiskan semua hasil panennya dan kedua juga selalu ingat dengan masa yang akan datang karena masa yang akan datang ditentukan oleh kerja keras yang dilakukan hari ini. Sebetulnya, budaya yang dimilikinya adalah bahwa manusia itu harus menyisihkan sedikit rejekinya untuk hari esok sehinngga hari esok bisa tetap bertahan hidup karena bisa memenuhi kebutuhan sehari-harinya walaupun terjadi musim paceklik.

(2) Nilai budaya hakekat dari hubungan manusia dengan alam. Nilai budaya hakekat dari hubungan manusia dengan alam sekitarnya adalah manusia berusaha menjaga keselarasan dengan alam karenamya mereka tidak serakah untuk memanen padi sebanyak-banyaknya akan tetapi disesuaikan dengan tanah itu sendiri. Mereka hanya menanam padi satu kali setahun berbeda dengan kita yang menanam padi tiga kali setahun. Kita mengeksploitasi alam demi kepentingan 
manusia. Alam juga seperti manusia yaitu alam perlu istirahat agar mereka bisa tumbuh sehat. Alam memiliki sumber daya yang terbatas. Manusia merupakan bagian dari alam. Sekecil apapun perilaku manusia terhadap lingkungan hidupnya harus segera diperbuat untuk bumi yang lebih baik,bumi adalah warisan nenek moyang yang harus dijaga dan diwariskan terhadap anak cucu kita sebagai generasi penerus pembangunan yang berwawasan lingkungan dan berkelanjutan.(Pudjiastuti; 2020)

(3) Nilai budaya mengenai hubungan manusia dengan sesama. Nilai budaya mengenai hubungan manusia dengan sesama adalah gabungan antara Orientasi kolateral, rasa ketergantungan kepada sesamanya (berjiwa gotong royong) dengan Orientasi vertikal, rasa ketergantungan kepada tokoh-tokoh atasan dan berpangkat. Hal ini terbukti dengan adanya kegiatan gotong royong pada setiap upacara yang diselenggarakan oleh kasepuhan sinar resmi sedangkan untuk memutuskan segala sesuatunya harus selalu bertanya kepada ketua adat Sinar resmi sehingga menunjukkan bahwa warganya sangat tergantung kepada ketua adatnya.

Proses penyesuaian diri warga kasepuhan sinar resmi dalam memahami dan menjalankan kaidah-kaidah dan nilai-nilai budaya yang ada: 1) Mengetahui nilainilai budaya yang berlaku pada beragam sektor kehidupan yang ada pada warga kasepuhan Sirna Resmi. Semua warga kasepuhan mengetahui semua Informasi tentang nilai budaya yang disampaikan secara lisan oleh orangtua masing-masing dan Ketua Adat. Warga kasepuhan Sirna Resmi ini tidak mempunyai kebiasaan untuk mencatat segala sesuatunya tetapi segalanya dilakukan dengan lisan. Selain itu juga dalam keseharian sering melihat aktivitas yang dilakukan oleh warga kasepuhan tersebut. 2) Mengerti apa yang dimaksud dengan nilai budaya yang ada di warga kasepuhan sinar resmi. Tahapan dalam proses penyesuaian diri selanjutnya adalah mengerti. Untuk bisa mengerti maka mereka selalu berdiskusi tentang makna yang terkandung di dalam nilai-nilai budaya tersebut dengan abah dan segenap pemangku adat yang ada di komunitas tersebut. 3) Memahami nilainilai budaya yang berlaku pada beragam sektor kehidupan yang ada pada warga kasepuhan Sirna Resmi. Earga kasepuhan bisa memahaminya dengan cara mampu untuk menjalankan nilai-nilai budaya tersebut dalam keseharian mereka. Mereka mengetahui apa yang seharusnya dilakukan agar terjaga apa yang telah diberitahukan pada mereka, mengerti apa makna dari pepatah itu dan memahaminya sehingga bisa diaplikasikan dalam kehidupan sehari-hari. Proses penyesuaian diri ini dikarenakan ada kewajiban dari warga untuk menjunjung tinggi nilai-nilai dan juga rasa hormat dari warga. Walaupun semua ini tidak tertulis tapi hanya lisan yang dituturkan oleh leluhur mereka agar dipahami dan dilaksanakan. Warga kasepuhan sirna resmi sangat patuh dalam menjalankan nilai-nilai budaya yang berlaku. Rasa patuh ini diperoleh berdasarkan 'penanaman nilai tentang kewajiban warga untuk patuh kepada ketua adat beserta para pemangku adat melalui petuah dari orang tua dan kokolot yang ada di kasepuhan sirna resmi tersebut.: Walaupun tidak ada paksaan dari siapapun tapi warga patuh atas kehendaknya sendiri. Percaya dan patuh apa yang dilakukan oleh abah dan sesepuh. Dari hasil wawancara, pernah ada warga yang tidak mematuhi norma yang berlaku tetapi akibatnya fatal karena orang tersebut menjadi sakit berkepanjangan karena didera rasa bersalah. Namun setelah warga tersebut berterus terang kepada abah maka warga tersebut sembuh kembali seperti sedia 
kala. Warga tersbut malu pada diri sendiri sehingga melaporkan sendiri apa yang telah dilakukannnya. Rasa percaya kepada abah yang membuat mereka malu untuk berbuat kesalahan. Rasa hormat yang membuat mereka percaya bahwa apa yang dilakukan oleh abah adalah demi kebaikan mereka.

Ada beberapa alasan yang melatar belakangi terjadinya pengaruh terhadap nilai-nilai budaya yang berlaku yaitu: 1)Warga kasepuhan sirna resmi mematuhi untuk mentaati nilai budaya ini karena rasa hormat terhadap kelompok ini sangat kuat. Kekuatan ini muncul dari dalam dirinya sendiri dan mereka tidak takut akan adanya perubahan yang mungkin bisa merubah nilai budaya mereka. Hal ini terlihat dari respon mereka terhadap kedatangan peneliti serta abah beserta ambu mempunyai handphone untuk alat berkomunikasi, motor dan mobil untuk alat transportasi. 2) Kesepakatan antar warga cukup kuat. Mereka tetap mempunyai kesepakatan untuk tetap menjaga daerahnya agar tidak dicampuri oleh orang lain. Tidak ada sanksi bagi warga masyarakat yang melanggar aturan. Seperti yang diucapkan oleh abah. Abah hanya memberikan pengertian dan petuah agar warga tersebut untuk berjanji agar tidak melakukannya lagi karena semua tata cara yang berlaku di komunitas adat tersebut demi kebaikan warga tersebut. Malahan orang yang melanggar norma adat tersebut lapor sendiri ke dukun dan minta nasihat darinya. Setelah itu menghadap abah. Abah tidak memberikan sanksi tapi warga tersebut malu sendiri dan kapok tidak akan melakukannya lagi. Budaya malu tumbuh sendiri sehingga warga tidak mau melanggar norma-norma yang sudah mereka sepakati bersama yang sangat berbeda dengan orang yang tinggal di daerah perkotaan. Sanksi ada tapi orang-orang yang berbuat kesalahan tidak mau mengaku walaupun bukti-bukti sudah nyata menunjukkannya bersalah.

\section{KESIMPULAN}

Pengaruh budaya terjadi melalui proses penyesuaian diri warga kasepuhan sinar resmi dalam memahami dan menjalankan kaidah-kaidah dan nilai-nilai budaya yang ada. Proses penyesuaian diri warga kasepuhan terhadap nilai-nilai yang berlaku adalah melalui tahapan proses mengetahui, mengerti, serta memahami nilai budaya yang berlaku melalui proses mendengarkan petuah dari oranng tua maupun abah serta kokolot yang ada di komunitas tersebut. Warga kasepuhan menyesuaikan dirinya dengan nilai-nilai budaya yang berlaku di kasepuhan Sinar resmi tersebut yaitu: 1) Orientasi nilai budaya mengenai hakekat dari hidup manusia yang berlaku di kasepuhan ini adalah Hidup itu baik, 2) Orientasi nilai budaya mengenai hakekat dari karya manusia yang berlaku pada kasepuhan Sinar Resmi adalah Karya itu untuk nafkah hidup, 3) Nilai budaya mengenai hakekat dan kedudukan manusia dalam ruang waktu di kasepuhan Sinar Resmi adalah warga sangat berorientasi ke masa yang akan datang. Hal ini bisa dilihat dari adanya tradisi menyimpan padi di lumbung padi yang disebut "leuit" dan sistem pertanian yang dilakukan warga kasepuhan sinar resmi. 4) Nilai budaya mengenai hakikat dari hubungan manusia dengan alam sekitarnya yaitu manusia harus hidup menyelaraskan dirinya dengan alam, 5) Nilai budaya mengenai hubungan manusia dengan sesama adalah gabungan antara Orientasi kolateral, rasa ketergantungan kepada sesamanya (berjiwa gotong royong) dengan orientasi vertikal, rasa ketergantungan kepada tokoh-tokoh atasan dan berpangkat.. Hal ini terbukti 
dengan adanya kegiatan gotong royong pada setiap upacara yang diselenggarakan oleh kasepuhan sinar resmi sedangkan untuk memutuskan segala sesuatunya harus selalu bertanya kepada ketua adat Sinar resmi sehingga menunjukkan bahwa warganya sangat tergantung kepada ketua adatnya. Selain itu juga, ada upaya penanaman nilai "Kepatuhan warga kasepuhan" dalam menjalankan nilai budaya.

\section{REFERENSI}

Afifah, A. Hastuti, Tulus Puji (2016), "Menarche Dipengaruhi Oleh Faktor ras, atau suku bangsa, factor iklim dan kebiasaan hidup", Jurnal Kebidanan,,5(9), 58-65. Diakses pada 6 Maret 2018.

Ekadjati, Edi Suhardi, (2014), Kebudayaan Sunda: Suatu Pendekatan Sejarah, Pustaka Jaya.

Hasan, Said Hamid (1996), Pendidikan Ilmu-Ilmu Sosial, Bandung:Rineka Cipta.

Hendarti, Latipah (2008), Menepis Kabut Halimun: Rangkaian Bunga Rampai Pengelolaan Sumber Daya Alam, Yayasan Obor Indonesia.

Kusumohamidjojo, B.(2000), Kebhinekaan Masyarakat Indonesia: Suatu Problematika Filsafat Kebudayaan, Jakarta:Grasindo.

Koentjaraningrat (2009), Pengantar Ilmu Antropologi, Jakarta: Rineka Cipta.

Mawaddahni,S (2017) "Filosofi Hidup Sebagai Wujud Kearifan Lokal Masyarakat Adat Kasepuhan Sinar Resmi”, [E-Journal]. Local Wisdom. 1(9),1-11. Diakses dari Jurnal unmer.ac.id. 15 Juni 2021.

Mutaqin, Z; Iryana, Wahyu, "Perubahan Sosial Budaya Masyarakat Kasepuhan Adat Banten Kidul Kabupaten Sukabumi”, Jurnal Studi Agama-Agama dan Lintas Budaya Vol.2.No.2 (2018) Penerbit UIN Sunan Gunung Djati Bandung.

Pitana, I.Gede dan Gayatri, Putu G (2005), Sosiologi Pariwisata, Yogyakarta:Andi.

Pudjiastuti, SR. M.Sutisna, P. Kurniati, Sopian, S.Rumiati, "Implementation of Information Meteorologi Climatologi And Geophysics On Economic Resilience", Systimatic Reviews in Pharmacy 12(3), 166-175,2021.

Pudjiastuti, Sri Rahayu,(2019), Penelitian Pendidikan, Yogyakarta: Media Akademi.

Pudjiastuti, SR. HS Iriansyah, Y Yuliwati, "Program Eco-Pesantren Sebagai Model Pendidikan Lingkungan Hidup" Jurnal Abdimas Prakasa Dakara 1(1),63-68,2021.

Pudjiastuti, SR (2020), Etika Lingkungan, Depok: Penerbit Gemala.

Soekanto (2006), Teori Sosiologi Tentang Perubahan Sosial, Jakarta: Ghalia Indonesia

Setiadi, Elly M.(2006), Ilmu Sosial Budaya Dasar, Jakarta: Kencana Prenada Media Group. 